\title{
Subjective Predictors of Safe and Risky Behaviours. Presentation of Selected Results of the Studies Among Workers in Non-Traditional Forms of Employment
}

\author{
Małgorzata Dobrowolska \\ University of Silesia \\ malgorzata.dobrowolska@us.edupl
}

\begin{abstract}
The paper presents selected results of the studies carried out among Polish workers in non-traditional forms of employment, using the Occupational Safety Culture Scale (Milczarek, 2000) consisting of 6 sub-scales: management commitment and participation; $\mathrm{OSH}$ training and analysis of accidents; values; relations between employees and affiliation to the company; responsibility and awareness; safe behaviours. All groups of the nine examined forms of flexible employment have declared the evaluation of occupational safety culture at the average level of 5-6 Sten, which shapes its following features. The paper presents selected results of the Author's own broader research project on a sample of workers in non-traditional forms of employment.
\end{abstract}

Keywords: atmosphere of occupational safety and health, flexible workers

\section{Introduction}

It is a common knowledge that dangerous behaviour and errors at work affect the accident rate (McSween, 1995). Subjective conditions of safe behaviour, although essential for safety, are not as important measurements of working environment analyses - the organisational and physical working conditions which are the most common variables. Safe behaviours are considered an effect of good safety management, and not a matter of individual circumstances (Goszczyńska, 1997; Studenski, 1996; Tyszka, 1992). And it is this issue that causes a lot of controversy.

Safe behaviours are understood as a function of ability and motivation to perform one's tasks safely, as an opposite to risky behaviours, an attitude towards changes, a result of preventive actions and safety management policy within the organisation. On the other hand, the behaviour of people in situations of risk can be associated with an analysis of advantages and disadvantages, which is a conscious choice, it can be a habit or result from such a habit, from following others' behaviours, executing orders, complying with bans and standards based on formal and legal aspects (Goszczyńska, 1997, after: Najmiec, Milczarek, 2003, p. 5).

\section{Theoretical background and an overview of selected studies}

In their study carried out on a group of drivers, Clark \& Prolisko (1979) found that a positive attitude to the rules and respect for other drivers manifests itself among people causing fewer accidents, than those who treat the legal provisions as imposed and restrictive in terms of freedom. Different nations are diverse when it comes to perception and acceptance of risk (Cutter, 1993; Goszczyńska, 1997). In the US, Norway and Poland, modern technologies are seen as more risky, than in Russia or Hungary (Mechitow, Rebrik, 1990). In societies which lower the risk, accidents are caused much more often. They are a result of unsafe conditions and behaviours, and the acceptance, consent and tolerance among others is a symptom of poor and undesirable safety culture which results in such accidents. In comparison to the UK, there is also a five times lower rate of deadly accidents. It results from the different attitude to OSH regulations, confidence in the preventive role of $\mathrm{OSH}$ regulations, the attitude of superiors to their subordinates who take the risk, the attitude of employees to their co-workers who take the risk, the attitude of superiors to employees who need to comply with safety standards, the attitude towards OSH training, the prestige of services and rank of OSH position and the involvement of employers in the organisation of safe working conditions. It has been noted that the role of the safety creator is played by 
the employer who creates the OSH policy, and, at the same time, defines threats, specifies standards, and promotes vigilance against threats (Pidgeon, 1994) (after: Studenski, 2000, p. 1-4).

Szczygielska (2011) discusses three approaches to changing the attitudes: cognitive approach that is based on changing the way people think; social approach, or imitating the behaviour of individuals considered to be role models; and behavioural approach understood as the effect of system of reinforcement and punishment, as an essential element for the safety-oriented behaviour in the workplace. Knowledge of the attitudes, or willingness to behave in a certain way in response to certain stimuli, allows to predict the human behaviour (Ajzen, 2001). There is a relationship between attitude and behaviour, due to the behavioural element, which is important for occupational safety and health (Harley, Bolman, Gregory, Eros, 2001; Szczygielska, Wszesińska, 2009). There is a positive relationship between positive attitudes to OSH and the accident rate value in the organisation (Donald, Canter, 1994). This allows to avoid mistakes, like a waste of time, discouragement, accidents at work. In the cognitive approach, the Author suggests to change the way of thinking about $\mathrm{OSH}$, using the information and a persuasive statement through training and direct talks with the staff. In the behavioural approach, behaviours, opinions and attitudes that are rewarded can be repeated and included in the routine behaviour. Such activities are used in order to strengthen the desired OSH attitudes. Diverse reinforcements and rewards clearly linked to the behaviour or attitude are a condition for the reward to be seen as desirable. Social approach to the changes of behaviour is based on the principles of learning by observing and memorising these behaviours. Gaining acceptance in the group requires the adoption of its standards and, therefore, the group moderates safety-oriented behaviours. As a result of modelling, it is possible to know the unknown pattern of behaviour, to refrain from negative behaviour, e.g., breaking OSH regulations, being easier to display certain behaviours, mimicking the behaviour of others (after: Szczygielska, 2011, p.1921).

The model of determinants of safe behaviour suggested by Najmiec \& Mielczarek $(2003$, p. 5) takes into account the individual and social variables. The former include emotions, like fear, anger, curiosity, and a sense of control, temperament traits (in particular, the need for stimulation, reactivity), seniority and level of professional experience, individual experience in emergency situations. Some of the selected social determinants have been singled out - the opinion of the management and co-workers in the field of compliance with the OSH regulation and an overall safety culture in the organisation (after: Najmiec, Milczarek, 2003, p. 5).

Szmajke (1992) has carried out a synthesis of personality determinants of resistance to difficult and threatening situations: self-esteem, guilt, neuroticism, sense of control over reinforcements and responsiveness, need for stimulation (Gal, Lazarus, 1975, Drwal, 1981, Modzelewska, 1983, after: Szmajke, 1992, p. 242). In the working conditions that are characterised by difficult situations, like overload, novelties, deprivation, people with low self-esteem, high level of neuroticism and sense of guilt, with an external sense of control and low level of reactivity function worse than people with opposite features. These individuals are also more prone to accidents at work (ibid., p. 242). The dimensions which are important for the perceived and accepted risk are: the level of anxiety in the face of danger, how imaginable causes and results of events are, how catastrophic or chronic the consequences are, how voluntary the taken risk is, how controllable the consequences of risky events are, how often the accidents happen, how inevitable the consequences of the risks are, how big and important the infringed human needs and values are (Goszczyńska, Tyszka, 1986, after: Szmajke, 1992, p. 244).

Ratajczak (1992) emphasises that emotions which will be triggered, and their role, depend on the dangerous situation. She applies the principle of interventions made and describes three such situations which differentiate the behaviour: situation of dangers which can be prevented and predicted; situation of dangers which can be eliminated and controlled; situation of dangers from which one can be protected, and finally - situation of dangers from which one should escape and evacuate. Each of these situations causes various emotions, however, anxiety is the dominant one (ibid., p. 197-198). Various emergency situations show different adequate behaviours, and fear can create favourable conditions for them or disorganise human behaviour, according to the principle that moderate anxiety favours right decisions, and excessive fear leads to inadequate behaviour. The Author systematises the effect of emotions (in the form of stress) on behaviour, while stressing that they may deform the perception of the situation by narrowing the area of awareness, distract, divert one's attention; they can demobilise employees to fight against the existing threats by the minimisation of meanings, due to stress as a dominant and competitive emotion; they can demobilise the standard workflow, thereby creating a greater risk; they may lead to exhaustion, excessive involvement of energy. Thus, stress can trigger involuntary dangerous behaviours (ibid., p.202). As part of the preventive actions, the Author suggests: training on the development of skills to deal with difficult 
situations, which allows temporary states of relaxation and self-control; creating models of efficient actions, hope and confidence in one's own strength; the formation of a positive self-image by supressing pessimistic attitudes (ibid., p. 204205). The second group of methods proposed by the Author concerns the professional selection - diagnosis of resistance to stress, emotional weakness (ibid., p. 206). The third group of conclusions relates to the optimisation of working conditions, adequately to human capabilities without causing frustration and tension in difficult situations, reducing environmental stressors (ibid., p. 207). The last group concerns the design of adequate warning and alarm systems, adapted to the sensory organs, which guarantee the effectiveness of the collection of information about the risks (ibid., p. 208).

Sztumski (2004) distinguishes three attitudes towards occupational safety: conformist attitude, hedonistic attitude and opportunistic attitude. Stasiła - Sieradzka (2012, p. 219-225, after: Sztumski, 2004, Horton and Lesile, 1970, Rybakowski, 2007, cf. 2013) lists twelve attitudes to safe behaviours. Indifferent attitude shows in people who do not care about any safety issues; while fatalistic attitude is characteristic of people with catastrophic visions who believe that accidents are inevitable; it is similar to cynical attitude when a person cares about their own safety but has no interest in general safety problems. Religious attitude is a belief in supernatural forces, in the power of faith. Sentimental attitude shows in people with the belief that all safety measures are utopian. On the other hand, scientific attitude is characteristic of people with an organised and rational approach to research, analyses and implementation of programs to improve safety. Conformist attitude expresses a passive approach to safety issues, the adoption of standards; opportunistic attitude, on the other hand, expresses a passive attitude to risks and aware exposure of life and health to risk in the name of one's own purposes. Enthusiastic attitude is typical for people interested in safety systems implementations; realistic attitude is characteristic of those who analyse the resources and costs involved in the organisational safety issues, without denying the very essence and seriousness of the problem. Pragmatist, on the other hand, is a person who analyses safety with a view to actual opportunities to reduce the risk and accident rate. Sceptical attitude is a belief that any improvement activity in the workplace does not affect the level of safety in the organisation. This quick overview of the above attitudes shows how different the motivations, beliefs, approaches and behaviours can be, in the face of danger and in relation to the issue of occupational safety. Even the same workplace, the same path of shaping safety-oriented behaviours, although it moderates and improves the attitude to safety, it still depends on the subjective factors of every single employee, regardless of the form of employment.

In his study of the efficiency of drivers, Najmiec (2008) proves that it is conditioned by the safety culture. The efficient behaviour of a driver itself depends on three conditions: accurate self-evaluation, assessment of one's own competence, and the right assessment of situation on the road, making the right decisions and executing efficient manoeuvres. The efficiency also depends on the age, personal and temperamental characteristics, experience, fatigue or monotony (after: Najmiec, 2003, p. 10). It can be argued that all jobs are similar, and the analogy is justified in terms of promoting safety culture, because the efficiency of actions is affected by momentary loss of attention, perception disorders associated with sleepiness and fatigue, personality traits, competencies and skills, nervousness and haste, as well as unawareness of the risks (cf.: Najmiec, 2008).

Szczygielska (2009) emphasises that greater professional experience, understood as longer service, causes greater resistance to the changes in the established patterns. Analyses of individual accidents in enterprises have confirmed that they are more common in the age group of long-serving workers. This almost automatically brings to mind the instructions for preventive measures, due to patterns handed down to the younger workers, and due to the fact that, particularly, groups of people with bigger experience have been affected in terms of creating OSH behaviours, regardless of the form of employment. The younger groups, up to 30 years old, are recommended to receive a message together with good practice possible to be used immediately, as younger workers find it easier to implement new behaviours in their work or adopt certain standards, than those with already formed abnormal behavioural styles (after: Szczygielska, 2009, p. 29).

Tyszka (1992) has presented a model employee behaviour in hazardous conditions. In most cases, every worker is affected by a diverse range of harmful or risky factors, which depend on the behaviour of the employee to varying degrees. Whether the employee is aware of the threatening factors depends on the information available to them. Sources of information affect the scope of the worker's knowledge about the risks. Perception of risk determines what is seen as dangerous or not, given the immediacy of the negative effects, catastrophic or chronic character of the risk, degree of familiarity with the threat, controllability of negative effects. After perception and evaluation of threats, it is time for behaviour determined by three elements: analyses of advantages and disadvantages associated with a particular behaviour, imitation or 
subordination to the group standards, and a formed habit. When choosing between different safe and dangerous behaviours, the three mechanisms mentioned can be involved to a various degree. Therefore, the creation of safe behaviours of employees should be done by providing reliable information about risks present in the workplace, proper assessment of risk, creating working conditions which favour choosing safe behaviours, using behavioural techniques to develop habits of safe behaviour and, finally, promotion of safe behaviour standards (after: Tyszka, 1992, p. 28-33).

As it has already been mentioned, Goszczyńska (1997) says that the behaviour of a worker in an emergency situation can be induced and regulated by three mechanisms: a conscious choice preceded by an analysis of advantages and disadvantages; a habit; imitation of the other people's behaviour or submission to group norms. The last two mechanisms are more unconscious, thoughtless, automated way to respond (after: Goszczyńska, 1997, p. 181-182). It results in the fact that the prophylaxis and measurement of occupational safety and health in terms of subjective impact should include both the improvement in the area of $\mathrm{OSH}$ and creation of favourable conditions for automated, unconscious activities related to the performance of duties.

\section{Presentation of own research}

The study has been carried out among workers in non-traditional forms of employment. It has been conducted among temporary workers employed by agencies, replacement workers, workers employed under civil law contracts, social economy employees, workers employed under fixed term contracts, part-time workers, teleworkers, seasonal workers and self-employed entrepreneurs or businesspeople.

Polish method developed in the Industrial and Organizational Psychology Lab at the Central Institute for Labour Protection (CIOP) covers similar elements of climate as the foreign methods, which include the involvement of management in OSH, employee participation, values shared in the field of $\mathrm{OSH}, \mathrm{OSH}$ training, responsibility and awareness of the staff in the field of OSH, safe behaviours. This tool is used to study the self-assessment of safety climate. M. Milczarek (2000) has created her own tool on the basis of very similar measurements. The tool has been used to measure the organisational climate in organisations using flexible forms of employment. Due to multiple statistical analyses obtained, this paper will mention selected conclusions.

As for the results of the variable against the analysis of individual differences, relationship with socio-demographic factors, the following variables have been chosen: gender, age, education, occupation, position, sector, industry, seniority, the number of employers, duration of employment contract, place of residence, marital status and the number of children.

It has been shown that the occupational safety variable is correlated with gender, age, education and occupation.

Analysis of the Mann-Whitney $U$ test has showed that there is a statistically significant relationship between gender and the result on the scale of occupational safety culture: $U=493371 ; p<.001$. The results obtained by women $(M=182 ; S D$ $=29.063)$ have been higher that among men $(M=177.46 ; S D=30.024)$. The Kruskal-Wallis one-way analysis of variance has showed that there is a statistically significant relationship between age and the results obtained on the scale of occupational safety culture: Chi-square (df 2$)=13.327 ; p<0.01$. The highest results have been obtained by the oldest employees at the age of 41-65 (median =183). Slightly lower results have been reported in the youngest group - 18-30 ( median $=181$ ), and the lowest ones - in the middle group (31-40 years old) (median $=176)$. The Kruskal-Wallis one-way analysis of variance has showed that there is a statistically significant relationship between education and the results obtained on the scale of occupational safety culture: Chi-square (df 2$)=28.671 ; p<.001$. The highest results have been obtained by employees with higher education (median $=183$ ). Slightly lower results have been reported in the group of employees with secondary education (median $=175$ ), and the lowest ones - in the group of respondents with primary and lower education (median $=173$ ). The Kruskal-Wallis one-way analysis of variance has showed that there is a statistically significant relationship between occupation and the results obtained on the scale of occupational safety culture: Chi-square (df 4)=46.835; $p<.001$. The highest results have been obtained by directors, CEOs and business owners (median = 193), then specialists and freelancers (median $=183$ ) and technicians and officials (median $=182$ ). Slightly lower results have been obtained by low-ranking employees - trade and services employees (median $=172$ ) and workers (median $=172$ ).

The lack of correlation of this variable has been obtained together with the other personal data: sector, industry, seniority, the number of employers, duration of employment contract, place of residence, marital status, the number of children. 
This means that, in accordance with Health \& Safety Executive, the assessment of high occupational safety culture, understood as "the result of individual and group values, attitudes, perceptions, competences and patterns of behaviour, as well as style and quality of safety management within the organisation", where an enterprise which has high safety culture is characterised by "communication based on mutual trust, perception of safety validity, trust in the efficiency of preventive measures" (Horbury, Bottomley, 1997, after: Milczarek, 2000, p. 17) will be affected by the group age of relatively mature and older employees with higher education, higher or middle-ranking - of specialised positions in the organisational structure, and the fact that the respondents are men. Younger employees, women and the less educated - with education lower than primary, as well as the lowest-ranking workers, tend to assess safety culture as low. Organisation as a system where the main role is played by the employees and adaptation to external conditions, will be assessed more pejoratively. Attitudes, behaviours, implemented values, or organisational culture traditions, defined as "norms, values, attitudes and generally accepted patterns of behaviour and procedures in the organisation, shared by all its members" (Milczarek, 2000, p. 18), are evaluated more critically, in accordance with the study results obtained.

The variable - flexible worker's perception of occupational safety climate, is among the environmental determinants of human behaviour at work. The mean score on the scale of occupational safety culture in the group of flexible workers was 179.33 with a range of the variable from 99 to 243 . The median is 179 , which means that half of the respondents has a score under 179 points. The negative value of skewness (slightly lower than zero) means that the distribution in relation to the vertical axis is symmetrical. The negative kurtosis informs that the distribution is slightly flattened. There are a little too many extreme values. The results obtained by flexible workers on the scale of occupational safety culture have been analysed with the regard to the form of their employment. The assumptions of analysis of variance have been met - normal distribution in sub-groups and homogeneity of variances. Analysis of variance has showed that the form of employment significantly differentiates the results of the respondents on the scale of occupational safety culture: $F(8,2107)=8.31$; $p<.001$. The results of the study show that the highest scores on the scale of occupational safety culture are obtained by self-employed workers (mean 190.9), while the lowest scores - by seasonal workers (mean 171.7). The results obtained can be explained by the specificity of the conditions associated with self-employment as a self-employed person usually creates them on their own, while employers of seasonal workers pay the least attention to occupational safety and health conditions.

In their early Polish study on safety culture, K. Burche \& A. Grzelak (1974) listed several factors that influenced safe or risky work undertaken by employees. Social pressure was one of the key ones - it was a group influence which affects the formation of behaviour, depending on the implemented environmental values. The second important finding was the fact that there was no clear procedures, systems and expectations of management or supervisors in the field of OSH, which does not favour the occupational safety. If OSH issues are of low importance in the system of values, no company's community groups pay attention to $\mathrm{OSH}$, and thus we can speak of poor safety culture. Unfortunately, the study has showed that the concept of a good employee is associated with an efficient employee who works fast, regardless of the safety requirements and, what is even worse, risky work is identified with high competence, and OSH regulations are perceived as unnecessary, and personal protective equipment is considered inconvenient and useless. Non-compliance with the regulations, failure to use security and personal protective equipment have proved to be the norm for many employees with the approval of superiors and management (Milczarek, 2000, p. 18). The study by R. Studencki (1999) shows that safety culture in Polish workplaces is much lower than the culture of English plants, which results in a high number of accidents and a high percentage of employees' diseases, however, these analyses have shown mean, average assessments (not low in any event) of occupational safety culture.

When describing the safety climate, Zolar (1980) conducted a study related to safety by analysing various aspects: the importance of OSH training, management attitude towards safety, the level of risk in the workplace, the status of OSH workers. The accumulated result has been specified by a level of safety climate, or the atmosphere in the plant perceived by employees and connected with occupational safety and health. The safety climate is associated with the overall level of safety, it determines either safe or risky job. The better the safety climate, the lower the number of accidents. The safety climate is a manifestation of the safety culture, and its monitoring favours maintaining high safety culture (Mearns, Flin, Gordon, Fleming, 1998). This study has shown a combined result of the organisational climate as average, according to the literature cited above. The analyses of additional questions about the accident rate in the organisation have been confirmed as well. 


\section{Conclusion}

The studies of safety culture in the nineties were based on observational measurement methods during visits, interviews with the staff, analysed documents and questionnaires completed by employees. Their purpose was mainly to examine the management commitment to safety issues, clarity of objectives and $\mathrm{OSH}$ procedures, employee involvement in safety policy, communication process in the organisation and the overall relationships between the employees. The study results clearly showed that there is a relationship between the accident rate and safety culture. The enterprises with high safety culture have: greater individual safety awareness, higher morale of employees, greater mutual trust between the management and employees, efficient organisational learning, focusing on safety issues, acceptance of personal responsibility for safety (Mielczarek, 2000, p. 19). The studies also showed a correlation between safety culture and other derived variables, like safety management, or technological risk with the accident rate (Horbury and Bottomley, 1997). The above has been also confirmed in the analyses carried out in the context of these professional problems of workers in nontraditional forms of employment.

In addition, Heinrich (1996) proves that most accidents are more connected with dangerous behaviour within the enterprise $(88 \%)$ than with the dangers resulting from working conditions, which due to the mean results obtained in this study is not without significance. The increase in safe behaviours is subject to the same conditions, than the ones described above - it prevents and reduces the number of injuries and accidents. Since behaviours are the result of attitudes and beliefs, prevention and prevention systems should be aimed at creating safety culture: strengthening the awareness and values of safety at work, particularly among women, people with lower education, lower-ranking workers, according to the obtained conclusions.

\section{Bibliography}

[1] Ajzen, I. (2001). Nature and operation of attitude. Annual Review Psychology, 52 (2001), 27-58.

[2] Bursche, K., Grzelak, A. (1974). Przyczyny nieprzestrzegania przez robotników przepisów i zasad bhp. Praca statutowa CIOP.

[3] Clark, A.W., Prolisko, A. (1979). Social role correlates of driving accidents. Human Factors 6, 655-659.

[4] Cutter, S. (1993). Living with Risk. London, Edward Arnold.

[5] Donald, I, Canter, D. (1994). Employee Attitudes and Safety in the Chemical Industry. Journal of Loss Prevention in the Process Industries, 7, 203-208.

[6] Drwal, R. (1981). Osobowość wychowanków zakładów poprawczych. Wrocław: Ossolineum.

[7] Gal, R., Lazarus, R.S. (1975). The role of activity in anticipating and confronting stressful situations. Journal of Human Stress, 1(4), 4-20.

[8] Gliszczyńska, X. (1990). Skala I-E w pracy. Technika pomiaru poczucia kontroli w sytuacji pracy. Warszawa: PTP.

[9] Goszczyńska, M. (1997). Człowiek wobec zagrożeń. Psychologiczne uwarunkowania oceny i akceptacji ryzyka. Warszawa: Wydawnictwo Żak.

[10] Harley, J., Bolman, H., Gregory, D., Eros, G. (2001). The effectiveness of training to change safety culture and attitudes within a highly regulated environment. Personnel Review, 30, 615-636.

[11] Horbury, C.R., Bottomley, D.M. (1997). Research into health and safety in the paper industry. Health \& Safety Laboratory, IR/RAS/98/2.

[12] Lis-Turlejska, M. (2002). Stres traumatyczny. Występowanie, następstwa, terapia. Warszawa: Wydawnictwo Żak.

[13] McSween, T.E. (1995). The Values Safety Process. New York: John Wiley \& Son Inc. 
[14] Mearns, K., Flin, R., Gordon, R., Fleming, M. (1998). Measuring safety climate on offshore installations. Work \& Stress, 12(3), 238-254.

[15] Mechitow, A.I., Rebrik, S.B. (1990). Studies of risk and safety perception in the USRR. W: K. Borcharding, O.I. Laricher, D.M. Meswsick (red.), Contemporary issues in decision making. Elsevier, Amsterdam.

[16] Milczarek, M. (2000a). Kultura bezpieczeństwa w przedsiębiorstwie - nowe spojrzenie na zagadnienia bezpieczeństwa pracy. Bezpieczeństwo Pracy, 10, 17-20.

[17] Milczarek, M. (2000b). Ocena poziomu kultury bezpieczeństwa w przedsiębiorstwie. Bezpieczeństwo Pracy, 5 , 17-19.

[18] Najmiec, A. (2008). Kultura bezpieczeństwa i psychologiczne uwarunkowania sprawności kierowcy - wybrane zagadnienia. Bezpieczeństwo Pracy, 7-8, 10-13.

[19] Najmiec, A., Milczarek, M. (2003). Indywidualne uwarunkowanie bezpiecznych zachowań pracowników. Bezpieczeństwo pracy, 6, 5-7.

[20] Ratajczak, Z. (1992a). Wpływ stanów emocjonalnych na zachowanie pracownika w sytuacji zagrożenia. W: T. Tyszka (red.), Psychologia i bezpieczeństwo pracy. Warszawa: Instytut Psychologii PAN.

[21] Ratajczak, Z. (1992b). Wsparcie społeczne w warunkach zagrożenia funkcjonowania człowieka w środowisku pracy. Psychologiczne problemy funkcjonowania człowieka w sytuacji pracy, 10, 19, UŚ. Katowice.

[22] Ratajczak, Z. (1992c). Źródła informacji o zagrożeniach i warunki skuteczności jaj oddziaływania. W: T. Tyszka (red.), Psychologia i bezpieczeństwo pracy. Warszawa: Instytut Psychologii PAN.

[23] Stasiła-Sieradzka, M. (2012). Participation of industrial and organizational psychology in creating safe working environment taking into account flexibility of employment. Zarządzanie. Teoria i praktyka, 2(6), 217-227.

[24] Studenski, R. (1996). Organizacja bezpiecznej pracy w przedsiębiorstwie. Gliwice: Wydawnictwo Politechniki Śląskiej.

[25] Studenski, R. (1999a). Kultura bezpieczeństwa Polaków i Brytyjczyków. Atest, 3, 43-44.

[26] Studenski, R. (1999b). Wypadki przy pracy. W: D. Koradecka (red.), Bezpieczeństwo pracy i ergonomia (s. 703735). Warszawa: CIOP.

[27] Studenski, R. (2000). Kultura bezpieczeństwa pracy w przedsiębiorstwie. Bezpieczeństwo pracy, 9, 1-4.

[28] Szczygielska, A. (2009). Promowanie bezpieczeństwa pracy w przedsiębiorstwach - na przykładzie Forum Liderów Bezpiecznej Pracy. Bezpieczeństwo Pracy, 4, 26-29.

[29] Szczygielska, A. (2011). Poznawcze, behawioralne i społeczne podejście do zmian postaw wobec bezpieczeństwa pracy. Bezpieczeństwo pracy, 4, 19-21.

[30] Szczygielska, A., Wrzesińska, J. (2009). Kształtowanie pozytywnej postawy pracowników wobec bezpieczeństwa pracy. Bezpieczeństwo pracy, 12(459).

[31] Szmajke, A. (1992). Osobowość w percepcji i akceptacji zagrożeń. W: T. Tyszka (red.), Psychologia i bezpieczeństwo pracy. Warszawa: Instytut Psychologii PAN.

[32] Tyszka, T. (red.). (1992). Psychologia i bezpieczeństwo pracy. Instytut Psychologii PAN, Warszawa.

[33] Zawadzki, B, Strelau, J. (1997). Formalna charakterystyka zachowania - Kwestionariusz temperament (FCZKT). Podręcznik. Warszawa: PTP.

[34] Zohar, D. (1980). Safety climate in industrial organizations: theoretical and applied implications. Journal of Applied Psychology, 65(1), 96-102. 